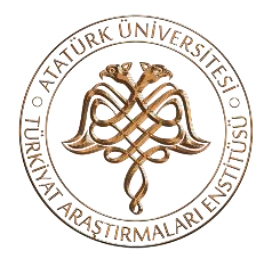

\title{
YANYA VILLAYETINDE BİR MUHACİR KASABASI: LOROS
}

\section{LOUROS: AN IMMIGRANT TOWN IN THE PROVINCE OF JANNINA}

\section{İLKAY ERKEN}

Arş. Gör. Ondokuz Mayıs Üniversitesi

Res. Assist. Ondokuz Mayis University

ilkay.erken@omu.edu.tr

iD https://orcid.org/0000-0002-7049-1058

Türkiyat Araştırmalanı Enstitüsü Dergisi-Journal of Turkish Researches Institute

TAED-63, Eylül-September 2018 Erzurum

ISSN-1300-9052

Makale Türü-Article Types : Araştırma Makalesi-Research Article

Geliş Tarihi-Received Date : $\quad$ 07.07.2018

Kabul Tarihi-Accepted Date : $\quad 20.09 .2018$

Sayfa-Pages : 557-571

doi : http://dx.doi.org/10.14222/Turkiyat4005

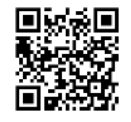

www.turkiyatjournal.com http://dergipark.gov.tr/ataunitaed

This article was checked by

$\checkmark$ iThenticate 



\title{
ATATÜRK ÏIIVERSIIIISSI \\ TÜRKIYAT ARAŞTIRMALARI ENSTITÜSÜ DERGISI \\ JOURNAL OF TURKISH RESEARCHES INSTITUTE \\ TAED-63, 2018. 557-571
}

\section{YANYA VILAYETINDE BİR MUHACIR KASABASI: LOROS \\ LOUROS: AN IMMIGRANT TOWN IN THE PROVINCE OF JANNINA}

\author{
İLKAY ERKEN
}

\begin{abstract}
Öz
Osmanlı Devleti 19. yüzyılda topraklarından bir kısmını terk etmek zorunda kalmıştır. Bunlardan en dikkat çekeni şüphesiz 93 Harbi olarak bilinen yenilgi ardından yaşanmıştır. Buna göre Osmanlı Devleti'nin Rumeli'deki topraklarından bazıları üzerinde artı egemenlik hakkı kalmaz. Bu gelişmelerin taraflarından birisi de Yunanistan'dı. Osmanlı Devleti'nin Yanya adıyla bilinen vilayeti ile Turhala sancağından Yunanistan toprak talep eder. Berlin Kongresi'nde Yunanistan'a toprak verilmesine ve Osmanl1-Yunan sinırının yeniden düzenlenmesine karar verilir. Yapılan müzakereler neticesinde Tirhala sancağı Yunanistan'da kalır. Yanya vilayetinde ise Yunanistan'n talepleri tamamıla kabul görmez. Narda Yunanistan'da kalacak şekilde Narda Irmağı sinır olarak kabul edilir. Bu şekilde çizilen yeni sınırlar neticesinde her toprak kaybındaki gibi muhacir meselesi ortaya çıkar. Terk edilen yerlerdeki Müslümanların Osmanlı tarafina göçleri başlar. Osmanlı yetkilileri bu şekilde yaşanacak göçler esnasında ahalinin sıkıntı çekmemesi için yakın bir yerde bir muhacir kasabası inşa etmek ister. Ayrıca terk edilen Narda'nın bir kaç saat mesafe ve karşısında bir Müslüman beldesinin bulunmasının yararlı olacağı düşünülür. $\mathrm{Bu}$ amaçla kurulan Loros kasabası Osmanlı tarafinda kalan köy ve çiftliklerin dâhil edilmesiyle bir kaza merkezi haline getirilir. Osmanlı Devleti çizilen yeni sınır sonrasında muhacirlerin iaşe ve iskânlarının sağlanmasında yaşanabilecek güçlükleri önlemeyi istemiştir. Bu nedenle muhacirler için yeni bir kasaba inşa etmiş ve bu kasabayı idari yapının da merkezi yapmıştır. $\mathrm{Bu}$ çalışmada kaynaklar temelinde muhacirler için kurulan kasabanın gelişim süreci ve nüfus yapısı ele alınmıştır.
\end{abstract}

Anahtar Kelimeler: Arnavutluk, Berlin Kongresi, Yunanistan, Narda, iskân

\section{Abstract}

The Ottoman State had to leave some of its territory in the $19^{\text {th }}$ century. The most striking of these was undoubtedly experienced after the defeat known as 93 Harbi. According to this, the Ottoman Empire no longer has the right to sovereignty over some of the territories in Rumelia. One of the sides of these developments was Greece. The territory from the province of the Ottoman Empire known as Yanya and the sanjak of the Tirhala was demanded by Greece. At the Berlin Congress, it was decided that Greece should be given land and that the Ottoman-Greek border should be restructured. At the end of the negotiations made, the Turhala remain in Greece. In the province of Yanya, the demands of Greece are completely unacceptable. The Narda River was regarded as the border as it remains in Greece. As a result of the new boundaries drawn in this way, the issue of the refugee comes up as every loss of land. The Muslims in the abandoned places begin to migrate to the Ottoman side. The Ottoman authorities want to build a nearby immigrant town so that the people will not suffer from this kind of migration. It is also believed that it would be useful to have a Muslim town in the vicinity of the abandoned Narda a few hours away. The town of Louros, established for this purpose, was transformed into a kaza center by the involvement of villages and farms on the Ottoman side. The Ottoman State thought to prevent the difficulties that could arise in providing the immigrants' food and settlement after the new border was drawn. The Ottoman State thought to prevent the difficulties that could arise in providing the refugees' possessions and possessions after the new border was drawn. For this reason they built a new town for the immigrants and made this town an administrative center. In this study, development process and population structure of the town established for immigrants are considered.

Key Words: Albania, Berlin Congress, Greece, Arta, settlement 


\section{Giriş}

Tanzimat sonrası dönemde Osmanlı Devleti'nin taşra teşkilatında 1864'te uygulamaya konulan ve 1867 'de yaygınlaştırılan vilayet idaresi Rumeli'deki Osmanlı topraklarının bir bölümünde Yanya vilayeti adılla teşkil edilmiştir. Güney Arnavutluk'un idari sınırları dahilinde 1867 yılında vilayet teşkil edilen Yanya, güneyde Yunanistan ile sınırdı. Vilayet, bir süre merkez sancak bulunan Yanya'nın dışında Tırhala, Berat, Ergiri ve Preveze sancaklarına münkısım edilerek idare edilmiştir ${ }^{1}$. Bu sancaklardan Tırhala, Yanya ve Preveze'nin Yunanistan ile sınırı bulunmaktaydı. Özellikle Rum Bağımsızlı̆̆ ardından kurulan Yunanistan Devleti ile siyasi bir söylem haline gelen Yunanlıların toprak taleplerinin bu üç sancağın sınırlarını kapsadığı görülmektedir. Bunun nedeni ise Yanya vilayetinin ve özellikle bu sancaklardaki nüfusun Ortodoks mezhebine mensup Arnavut, Ulah ve Rumlar olmasıdır. Yunanistan'a göre vilayet dâhilindeki Ortodokslar aslında, Osmanlıların da değimi ile, Rum olmalarından sebeple kendi soydaşlarıdır. Haliyle bu kişilerin yaşadığı topraklar da Yunanistan'ın hakkıdır.

Yunanistan'ın Rum Bağımsızlığı ardından siyasi olarak sürekli dile getirdiği bu toprak talepleri 93 Harbi ile bir firsata dönmüştür. Yunanlılar ile Osmanlıların fiziki olarak savaşmadıkları halde Berlin Kongresi neticesinde Osmanlı-Yunan sınırının düzenlenerek Yunanistan'a toprak terki kararı alınmıştır. Bunun üzerine taraflar arasında süren müzakerelere çeşitli defalar İtalya, Fransa ve İngiltere gibi devletlerin öneri ve müdahaleleri eşlik etmiştir. Osmanlı Devleti'nin, özellikle Karadağ’a toprak terkine karşı örgütlenen Arnavutları da bahane ederek Yunanistan'a toprak vermeye istekli olmaması süreci uzatmıştır ${ }^{2}$. Ancak Berlin Kongresi'ne taraf devletlerin baskısı üzerine Osmanlı Devleti Yenişehir dışında Tırhala sancağını ve Yanya vilayetinin Preveze sancağında daha önceden sancak merkezi de olan Narda'yı Yunanlılara terk etmek zorunda kalmıştır. Böylece Osmanlı Devleti'nde daha 18. yüzyıl itibariyle başlayan göç hareketlerinin 19. yüzyılda ${ }^{3}$ Berlin Kongresi ardından yaşanan sürecin Yanya vilayetine tesir eden kısmı gün yüzüne çıkmıştır.

Kaybettiği savaşlar ${ }^{4}$ neticesinde Osmanlı Devleti'nin topraklarındaki demografik hareketlerden dolayı devletin çeşitli alanlarda tedbirler alması gerekmiştir. Bulundukları toprakları terk ederek çeşitli nedenlerle Osmanlı topraklarına gelen göçmen, muhacir ve mübadillerin ${ }^{5}$ iaşelerinin sağlanması, barınmaları için uygun yerlerin tespit edilerek

\footnotetext{
${ }^{1}$ Tırhala daha sonradan vilayet sınırlarından ayrılmış, müstakil sancak yapılmıştır. Bk. Y. V. S. , H. 1288/M. 1871, s. 102.

${ }^{2}$ Beytullah Destani (ed.), Albania and Kosovo; Political and Ethnic Boundaries 1867-1946, Archive Editions, Hobbs The Printers Of Southampton, Bristol, 1999, p. 224-225.

${ }^{3}$ Derya Derin Paşaoğlu, "Muhacir Komisyonu Maruzatı'na Göre (1877-78) 93 Harbi Sonrası Muhacir İskânı", History Studies, Vol. 5, Issue 2, March 2013, p. 348-349.

${ }^{4}$ 18. Yüzyıl ile başlayan süreçte Osmanlı Devleti sınırlarına toplu göçler yönelir. Bk. Sevinç Qasımova, "XIX Yüzyılda Kuzey Kafkasya'dan Anadolu'ya Göçler: Tarihçilik Açısından Göçün Nedenleri, Sorunları ve Sonuçları", Akademik Tarih ve Düsünce Dergisi, C. IV., S. XIII, Aralık 2017, s. 596.

${ }^{5}$ Göçmen ve muhacir kelime anlamı bakımından eş anlamlıdır. Fakat Osmanlı yetkililerince farklı manalarda kullanılır. Mevsimsel göçler, padişahın İstanbul'dan Edirne'ye gitmesi, bir ailenin şehir değiştirmesi için göç kelimesi kullanılmıştır. Kırım Harbi, 93 Harbi ve Balkan Savaşları sonrasında yurdunu terk etmek zorunda kalanlara ise muhacir denilmiștir. Mübadiller ise 1912-1923 arasında iltica edenler ile Lozan'dan sonra gelenler olarak ikiye ayrılmaktadır. Balkan Harbi ardından yurtlarına geri dönmek üzere Osmanlı topraklarına gelen ve bir
} 
buralara belirli bir düzen dâhilinde ve güvende ${ }^{6}$ nakledilmelerine çalışılmıştır. Bu ise çoğunlukla malî nedenlerle aksaklıkların yaşanmasına sebep olmuştur. Topraklarını terk ile göç edenlerin ihtiyaçlarının karşılanarak mevcut demografik yapı ve düzene de sıkıntı vermeden bu kişilerin iskânlarının sağlanması önemli bir süreçti. Bunun için olsa gerek Osmanlı Devleti yetkilileri sırf bu iş ile meşgul olacak bir birim dahi ihdas etmişlerdir?

Osmanlı Devleti'nin idari birimleri dâhilinde teşkil edilmesi ihtiyacı duyulan birimlerin yanında yaşanan nüfus hareketlerinin muhtemel sosyal sonuçlarının da dikkate alınmasıyla bazı durumlarda yeni yerleşim birimleri teşkil edilmiştir ${ }^{8}$. Bunlar mahalle, köy ve hatta nadiren de olsa kasaba ölçeğinde olabilmekteydi. Osmanlı yetkilileri vatanlarını terk ederek göç etmek durumunda kalanların terk ettikleri yerlerdeki ekonomik faaliyetlerine uygun mahallere iskânlarına özen göstermiştir ${ }^{9}$. Ayrıca iskân edilecek yerde hâlihazırda bulunan ahali ile mizaç olarak da uyuşup uyuşmadıklarına dikkat edilmekteydi. İskân edilecek ahalinin geçimlerini devletin imkânlarına bağlı kalmadan sürdürebilecekleri yerlerde iskân edilmelerine de çalışılmaktaydı. Böylelikle zaten mali bakımından sıkıntı içindeki bütçeye uzun süre yük olunmayacak, göç eden ahali de geçimlerini temin edebilecekti. Bunun için ise muhacirlerin kullanımda olmayan ve ekilebilir arazilerin bulunduğu yerlere iskân edilmelerine özen gösterilmiștir. $\mathrm{Bu}$ hassasiyetler temelinde gerçekleşen nüfus hareketliliğine dair düzenlemelerde bazı hallerde bu ahaliye mahsus yerleşim yerleri seçilirken Yanya'da olduğu üzere askeri ve siyasi önceliklerle de yerleşim birimleri teşkil edilebilmiştir. Bu çalı̧̧mada böyle bir niyetle kurulan ve Narda muhacirlerinin iskân edildiği Loros arşiv malzemeleri temelinde ele alınmıştır.

\section{Narda'nın Terki Ardından Loros Kasabası ve Kazasının Teşkili}

Osmanlı Devleti'nin siyasi sınırlarının daralmasına yol açan 93 Harbi Yanya vilayetini de etkilemiştir. Bu savaşın neticesinde Tırhala sancağı Yanya vilayetinden

anlamda mülteci sayılanlar daha sonra şartların bu yönde gelişmemesi nedeniyle iskân edilerek muhacir sıfatını kazanırlar. Ardından mübadele sözleşmesi ile de mübadil olarak tanımlanırlar. Bk. Nedim İpek, Selanik'ten Samsun'a Mübadiller, Cevdet Yılmaz (haz.), Samsun Büyükşehir Belediyesi Yayınları, Samsun 2010, s. 4-5.

${ }^{6}$ Naci Şahin, "XIX. Yüzyıl Sonrasında Anadolu'ya Yapılan Göç Hareketleri Ve Anadolu Coğrafyasındaki Sosyokültürel Etkileri”, Sosyal Bilimler Dergisi, s. 63.; Züriye Çelik, “ Osmanlının Zor Yıllarında Rumeli Göçmenlerinin Türk Basınındaki Sesi: Muhacir Gazetesi (1909-1910)”, Selçuk Üniversitesi Türkiyat Araștırmaları Dergisi, S. 28, 2010, s. 407.

${ }^{7}$ 1789-1839 tarihlerinde bu iş özelinde bir teşkilatlanma yoktur. Bu tarihlerde genelde İstanbul'da Şehremaneti, diğer vilayetlerde ise belediyelere benzer kurumlar nüfus hareketleriyle ilgilenmekteydi. Lakin 1860 yllında Osmanlı topraklarındaki muhacirlerin yoğunlaşması üzerine bu işe mahsus bir kurumun teşkiline ihtiyaç duyulur. Böylelikle Muhacir Komisyonu kurulur. 1877-78 Harbi ardından ise daha kapsamlı olarak İdare-i Umumiyye-i Muhacirin Komisyonu ihdas edilir. Bk. Nedim İpek, Rumeli'den Anadolu'ya Türk Göçleri, Türk Tarih Kurumu Basimevi, Ankara, 1999, s. 68-69.

${ }^{8}$ Yeni yerleşim birimlerinin kurulmasında göçmenlerin geçimlerini sağlayabilecekleri yerlerin teminine özellikle dikkat edilir. Muhacirler için temin edilecek yerleşim birimlerinin bulunmasında ekonomik unsurların yanında güvenlik ve sıhhi meselelere de dikkat çekilmekteydi. Bk. Ayşe Pul, "1877-78 Osmanlı-Rus Savaşı Sonrası Beykoz'da Muhacirler İçin İskân Yeri Çalışmaları”, Tarih Okulu Dergisi, S. XV, Eylül 2013, s. 159, $165-166$.

${ }^{9}$ Devletin üretime katkıda bulunacak nüfusu arttırmak amacının da muhacirlerin iskanında dikkate alındığı görülmektedir. Bk. Ferhat Berber, “19. Yüzyılda Kafkasya'dan Anadolu’ya Yapılan Göçler”, Karadeniz. Araştırmaları, S. 21, Güz 2011, s. 22. 
ayrılarak müstakil hale getirilmiştir. Ardından Yunanistan ile yapılan sınır düzenlemesi ile Osmanlı idaresinden tamamen çıkmıştır. Yanya vilayetinin Preveze sancağından ise Narda kasabası ile aynı isimdeki kazaya bağlı bazı yerleşim birimleri Yunanistan'a terk edilmiştir. Böylece Yunanistan-Osmanlı sınırı Narda Suyu ile çizilmiştir ${ }^{10}$. Bu şekilde Berlin Muahedesi'nin 24. maddesi ve 13. protokolü kapsamında Yunanistan'a terki gereken topraklardan Yanya vilayetinin hissesine düşen kısmı Narda olmuştur ${ }^{11}$.

Preveze sancağından Narda'nın Yunanistan'a terki ${ }^{12}$ esnasında Hristiyanların sakini oldukları köylerden bazıları Osmanlı Devleti sınırında kalmıştır. Bu köylerdeki ahalinin dini işlerinde eskiden bağlı oldukları Narda metropolitliği artık Yunanistan sınırında kaldığından Preveze'de yeni bir metropolitlik kurulmuştur. Böylece Osmanlı Devleti'nin sınırlarında kalan eski Narda kazası dâhilindeki köy ve çiftlik ahalisinin dini ihtiyaçları giderilmeye çalışılmışıır ${ }^{13}$.

Berlin Muahadesi sonrasinda yapılan müzakereler ile Haziran 1881'de Yunanlılara teslim edilen ${ }^{14}$ Narda kasabasının ardından Osmanlı yetkilileri buradan göç edecek muhacirlerin iskânına elverişli yer teminine girişirler. Bunun için ise mevcut yerleşim birimlerinden ziyade kurulacak bir kasabanın uygun olacağı düşünülmüştür. Nitekim Narda'nın hemen karşısında ${ }^{15}$, Narda Köprüsü'nün diğer tarafinda, Loros adında bir muhacir kasabasının teşkili tasarlanmıştır ${ }^{16}$. Bu kasabanın teşkili gerekçesinin başında Müslüman muhacirlerin iskânına elverişli bir İslam Beldesi oluşturmak vardır. Çünkü Yunanistan'a terk edilen Narda kasabası dâhilindeki Müslümanların Narda'ya uzak bir yere nakilleri hem devlet hem de ahali için müşkilata neden olacakt ${ }^{17}$. Daha özelde ise Yunanistan'a terk edilen Narda'nın nüfusunun büyük kısmının Hristiyan olması da Loros'un kurulmasının bir nedeniydi. Buradaki Hristiyanların Osmanlı Devleti tarafinda kalan bağ ve bahçelerini kullanmaya devam edecek olmaları bu düzenlemede etkiliydi ${ }^{18}$. Öyle ki artık Yunanistan vatandaşı bulunan Hristiyanların bağ ve bahçelerini kullanmak üzere Osmanlı tarafina geçtiklerinde yapmaları muhtemel olumsuz faaliyetlerin önlenmesi düşünülmekteydi. Böylece muhacirlerin iskânı için kurulan Loros kasabası aynı isimli kazanın da merkezi olmuştur. Artık Preveze sancağında Narda kasabası yerine Loros kasabası, Narda kazası yerine Loros kazası mülki taksimattaki yerini almışııı' ${ }^{19}$.

\footnotetext{
${ }^{10}$ Destani (ed.), Albania and Kosovo..., p. 272.

${ }^{11}$ Belgenin Ekim 1881 tarihli olması gerekmektedir. Bk. B. O. A. , Y.EE. 43-222, 1 Rabiulahir 1327/22 Nisan 1909.

12 Narda'nın Yunanlılar'a terki 24 Haziran 1881'dedir. Yunanlılar, Narda'nın Osmanlı'dan kurtarılmasını 24 Haziran'da yaptıkları kutlamalar ile anarlar. Bu kutlamalar Narda şehbenderliğinin raporlarında görülür. Bunlardan 1898 yılındaki kutlamada Osmanı askerlerinin giydiği fese Yunanlı askerlerin ve ahalinin küfür ettiği Loros kaymakamlığına bildirilir. (Bk. B. O. A. , DH.ŞFR. 225-148, 27 Haziran 1314/9 Temmuz 1898.) Şehrin Yunanlilara teslimi ise 6 Temmuz 1881'e tesadüf eder. Bk. İdris Bostan, "Narda”, DİA, C. 32, Türkiye Diyanet Vakfi Yayınları, İstanbul 2006, s. 386.

${ }^{13}$ B. O. A. , I.DH. 1295/2-101964, 21 Zilhicce 1298/14 Kasım 1881.

${ }^{14}$ B. O. A., DH.ŞFR. 225-148, 27 Haziran 1314/9 Temmuz 1898.

${ }^{15}$ Antonio Baldacci, Itinerari Albanesi (1892-1902), Presso La Reale Societa Geografica Italiana, Roma 1917, p. 174.

${ }^{16}$ B. O. A. , ŞD. 2090-31, 27 Mart 1298/8 Nisan 1882.

${ }^{17}$ B. O. A. , SSD. 2091-9, 12 Mart 1300/24 Mart 1884.

${ }^{18}$ B. O. A. , Y.A.RES. 20-24, 18 Cemazeyilahir 1300/26 Nisan 1883.

${ }^{19}$ B. O. A. , ŞD. 2091-9, 12 Mart 1300/24 Mart 1884.
} 
Narda kasabasının Yunanistan'a terki üzerine teşkil edilen Loros'un Osmanlı istatistiklerinde gösterilmesi hemen olmaz. 1881 tarihli devlet salnamesinde Loros Yanya vilayetinin kazası değil nahiyeleri arasındadır. Fakat aynı salnamede Narda hala Preveze sancağının bir kazası olarak vilayetin mülkî taksimatındadır. 1884 yılına kadarki kayitlarda Narda'nın ve Loros'un bu durumu devam eder. Bu yıl itibariyle Loros nahiye olarak gösterilmeye devam ederken Narda, normal olarak vilayetin mülkî sınırları içerisinde değildir. 1885 yılında ise Loros kazası, teşkil edildiği esnada belgelerde de belirtildiği şekli ile, Preveze sancağındadır. Aslında Osmanlı Devleti'nin istatistiklerinde genellikle vilayet dahilindeki idari değişiklikler daha düzenli bir şekilde takip edilmektedir. Loros ve Narda için görülen ve üç yıl kadar gecikmeli olan bu durumun nedeni ise açık değildir. Benzer şekilde 1883 yılında vilayet dahilindeki sancakların ve sancaklar dahilindeki idari birimler de hatalıdir ${ }^{20}$.

Narda'nın Yunanistan'a terki ile Loros kazasının idari birimlerinin düzenlenmesine başlanmıştır. Bunun için öncelikle Yunanistan'a bırakılan Narda'daki hükümet yetkilileri maliyesi ile birlikte Loros'a nakledilmiştir ${ }^{21}$. Ancak sonraki işlemlerde yapılan bu değişiklikle alakalı olarak hazinenin bilgisinin olmadığı anlaşılmıştır. Nitekim dahiliye nezareti buna dair muamelenin yapılması için sadarete bilgi vermiştir. Bunun üzerine sadaret tarafından maliye nezareti de bilgilendirilerek duruma açıklık getirilmiştir ${ }^{22}$. Kaymakam ve naib gibi görevlilerin Loros'a tayinleri üzerine kasabada hükümet konağ ile bir de mescit inşa edilmiş̧iir ${ }^{23}$. Kasabada belediye işlerinin yürütülmesi için ise belediye dairesi de vakit kaybedilmeden kurulmuştur ${ }^{24}$.

Loros kazasının idari tertibatının ${ }^{25}$ düzenlenmesi üzerine mülki birimlerinin dağılımına ilişkin işlemlere girişilmiştir. Bunun için daha önceden Narda kazasının bir nahiyesi bulunan ve sonradan lağvedilen Çemernik'in yeniden nahiyeye tahviline karar verilmiştir. Çemernik'in nahiye teşkilinin nedeni tıpkı Loros'un teşkilinde olduğu gibi Yunanistan tarafindan yapılması muhtemel eşkiyalık faaliyetlerini önlemektir ${ }^{26}$. Böylelikle Yunanistan tarafindaki eşkiyaların firsat buldukça Osmanlı sınırını aşarak yaptıkları saldırıların önlenmesi düşünülmekteydi. Böylece Çemernik nahiyesinin 27

\footnotetext{
${ }^{20}$ Preveze sancağının Koniçe ve hatta Premedi'ye kadar uzandığı halde Loros'un Yanya sancağında gösterilmesi buna sadece bir delilidir. Bk. D. S. , H. 1298/M. 1881, s. 89, 90. ;D. S. , H. 1299/M. 1882, s. 143. ; D. S. , H. 1300/M. 1883, s. 273-275. ; D. S. , H. 1301/M. 1884, s. 32. ; D. S. , H. 1302/M. 1885, s. 43.

${ }^{21}$ B. O. A. , SD. 2090-31, 29 Şevval 1299/12 Eylül 1882.

${ }_{22}^{2}$ B. O. A. , SD. 2090-31, 6 Muharrem 1300/17 Kasım 1882.

${ }^{23}$ B. O. A. , Y.A.RES. 20-24, 18 Cemazeyilevvel 1300/26 Nisan 1883.

${ }^{24}$ Belediye reisi 1892 'de İzzet Efendi, 1894 'te Tevfik Efendi'dir. Bk. Y. V. S. , R. 1308/M. 1892, s. 219. ;Y. V. S. , R. 1311/M. 1894, s. 170.

${ }^{25}$ Gerçekten kısa bir sürede kaza dahilindeki idari birimlerin teşkili gerçekleşir. Kaza idare meclisi, naib, bidayet mahkemesi, maarif komisyonu gibi birimler ile mal müdürü, evkaf müdürü, telgraf ve posta memuru, pasaport muayene memuru, sandık emini, tahrirat katibi, nüfus katibi, vergi katibi, ziraat bankası memuru, reji memuru, duyun-u umumiye ve rüsumat işleriyle ilgili memuriyetlerin görevlerine başladıkları anlaşılır. Bunda Narda kazasındaki idari heyetin doğrudan Loros'a nakledilmesinin etkisi büyüktür. Bk. Y. V. S. , H. 1306/M. 1888, s. 111-112. ;Y. V. S. , R. 1308/M. 1892, s. 218-219. ;Y. V. S. , R. 1311/M. 1894, s. 169-170. ;Y. V. S. , M. 1319/M. 1901, s. $175-177$.

${ }^{26} 800$ kuruş müdür ve 400 kuruş katip maaşı tahsis edilir. Bk. B. O. A. , I.ŞD. 73-4307, 3 Cemazeyilevvel 1302/18 Şubat 1885.
} 
Ağustos 1885 tarihi itibariyle teşkil edildiği ve nahiye heyetinin ikametine uygun bir konağın da kiralandığı anlaşılır ${ }^{27}$.

Loros kazası dahilindeki idari birimlerin düzenlenerek yeni nahiyelerin teşkili süreci Çemernik ile sınırlı kalmaz. 93 Harbi ardından Yunanistan lehine yapılan sınır düzenlemesi ve Narda'nın terki ardından Loros'un bir muhacir kasabası olarak kurulması ve aynı isimli kazanın da merkezi olması üzerinden geçen yıllara rağmen idari ve mülki değişiklik talepleri kesilmez. Preveze mutasarrıflığı tarafından dile getirildiği üzere Loros kazası teşkili esnasında birinci sınıf kaymakamlık olarak mülki dağılımdaki yerini alır. Ancak ilgili mutasarrıflığın ifadesi ile bölgede geniş ve önemli bir mevkideki Margılıç gibi bir yerin ikinci sınıf kaymakamlık iken Loros gibi küçük ve gelişmemiş bir yerin birinci sınıf kaymakamlık olmasının uygun olmadığı vilayete bir mazbata ile bildirilir. Yanya vilayeti de Preveze mutasarrıflığının Margılıç'ın birinci, Loros'un ikinci sınıf kaymakamlık olması doğrultusundaki mazbatasını dâhiliye nezaretine iletir ${ }^{28}$. Ancak ilerleyen yıllarda duruma ilişkin bilgiler kontrol edildiğinde mutasarrıflığın bu talebinin kabul görmediği anlaşılır. 1912 yılında Loros'un birinci sınıf kaymakamlık durumu korunur ${ }^{29}$. Bunda Loros'un askeri bakımdan Yunanistan sinırındaki konumunun etkili olduğunu ileri sürmek yanıltıcı olmayacaktır. Preveze mutasarrıflığının neticesiz kalan bu girişiminin ardından Loros'ta nahiyeler teşkil edilir. Nitekim yapılan düzenlemeler neticesinde Loros'un Çemernik, Kervansaray, Lake ve Ova isimli dört nahiyesi bulunur $^{30}$. Kazanın mülki taksimatı bir süre daha bu şekilde muhafaza edilir ${ }^{31}$. Lakin Preveze mutasarrıflığının Loros kazasının mülki yapısıyla ilgili girişimleri bununla sınırlı kalmaz. 1900 yılında mutasarrıflığın beyanıyla vilayete arz edilen mazbataya göre Loros kazası dahilindeki nahiyelerin yeniden düzenlenmesi istenir. Bu nahiyeler aşağıdaki gibidir.

Tablo 1: Loros Kazasında Teşkili Düşünülen Nahiyeler ${ }^{32}$.

\begin{tabular}{|l|l|l|l|l|}
\hline Nahiye & Merkez & Köy-Çiftlik & Hane & Nüfus \\
\hline Lelove & Kranina Çiftliği & 10 & 1074 & 5109 \\
\hline Kervansaray & Sula Çiftliği & 7 & 440 & 1793 \\
\hline Selhore & Selhore İskelesi & 10 & 282 & 1498 \\
\hline Köprübaş1 & Nihor Çiftliği & 13 & 662 & 3172 \\
\hline
\end{tabular}

Görüldüğü üzere mutasarrıfllğın kurulmasını talep ettiği yeni nahiyeler içinde Kervansaray varlığını korurken Çemernik, Ova ve Lake nahiyeleri lağvedilmek istenir. Bunların yerine ise Lelove, Selhore ve Köprübaşı isimli nahiyelerin teşkili düşünülür.

\footnotetext{
${ }^{27}$ Konağın icarına dair ödenek yetersizliğinden sebeple daha sonradan kesilir. Bk. B. O. A., DH.MKT. 1711-108, 5 Saban 1307/27 Mart 1890.

${ }^{28}$ B. O. A. , SD. 2095-12, 20 Safer 1309/25 Eylül 1891.

${ }^{29}$ Ali Tevfik, Mufassal Memalik-i Osmaniye Coğrafyası, Artin ve Asadoryan ve Mahdumları Matbaass, İstanbul 1329 , s. 220.

${ }^{30}$ Y. V. S. , H. 1306/M. 1888, s. 113. ;Y. V. S. , R. 1308/M. 1892, s. 220.

${ }^{31}$ Nahiyeleri değişmeden varlıklarını korur. Bk. Ali Cevad, Memalik-i Osmaniyenin Coğrafyası, C.III., Kasbar Matbaas1, İstanbul 1314, s. 713.

${ }^{32}$ Islahat layihası doğrultusunda 10 Ekim 1899'da Preveze mutasarrfilı̆ıınca arz edilen pusuladır. Bk. B. O. A. , DH.TMIK.S. 28-85, 1 Ramazan 1317/3 Ocak 1900.
} 
Bunun, Yunanistan sınırındaki güvenlik tedbirleriyle ilgili çalışmalarda dikkate alınarak düşünülen değişikliklerden olduğu söylenebilir. Ancak burada dikkat edilmesi gereken bir durum bulunmaktadır. 1888 ve 1892 tarihli kaynaklarda belirtilen nahiyeler ve ardından Preveze mutasarrıflığında teşkili düşünülen nahiyelerin tam anlamıyla teşkil edilmiş olduklarını söylemek güçtür. Bunlardan Loros kazasının teşkili ile birlikte düzenlenen Çemernik dışındakilerin aslında nahiye heyetlerinden yoksun oldukları düşünülebilir ${ }^{33}$. Nitekim 1898 yılına ait farklı kaynaklarda Loros kazasının sadece Çemernik nahiyesine sahip olduğu belirtilir ki bunun nedeninin adı geçen nahiyelerden sadece Çemernik'te nahiye heyetinin bulunduğu ileri sürülebilir ${ }^{34}$.

Loros kasaba ve kazasının teşkili ile idari birimlerinin düzenlenmesi ${ }^{35}$ ardından zaten küçük olan Loros kasabasının ticari faaliyetlerinin ve mali durumunun iyileştirilmesine dair icraatlar yapılır. Loros'un Narda Köprüsü’nün başındaki dükkanlar nedeniyle ticari bakımdan güçlükler yaşadığı gerekçesiyle bu dükkanların kaldırılması düşünülür ${ }^{36}$. Loros'un mali durumuyla ilgili sslahat neticesinde kazanın vergi gelirlerine göz atılarak hangi idari hizmete ne kadar harcama yapıldığı gösterilir. Bu şekilde kazanın gelir ve gider dengesinin sağlanarak teşkili sırasında idari sınırlarına verilen çiftliklerden elde edilen üretime özen gösterildiği söylenebilir. Bu açıdan Loros'un Yunanistan'a terk edilen Narda'dan gelecek muhacirlere mahsus bir kasaba olarak teşkil edilmesinin yanında mali özelliklerine de hassasiyet gösterildiği söylenmelidir ${ }^{37}$.

\section{Loros Kasaba ve Kazasının Demografik Yapısı}

Loros kasabası konum olarak sancak merkezi olan Preveze'nin doğusunda, Yunanistan'a terk edilen Narda Köprüsü'nün Osmanlı tarafinda ve Narda'ya 3-4 saat ${ }^{38}$ mesafededir. Kasabada teşkili esnasında inşa edilen ufak bir cami ile 40-50 kadar dükkân, bir hamam ve iki han bulunmaktadır. Kaza genelindeki yapılar ise 115 kilise ve manastır, birisi rüştiye ${ }^{39}$ olan $17 \mathrm{okul}^{40}$, yedi han, beş firın, 117 dükkân ve mağaza, üç mescit ve camiden ibaretti. Kazadaki camilerden ilki söylendiği üzere kasaba merkezindedir. Diğeri Narda Köprüsü yakınında Gazi Faik Paşa tarafından 75.500 kuruş geliriyle birlikte H. 900'de inşa ettirilen minareli bir camidir. Sonuncusu ise kazanın Istaroke köyündedir ${ }^{41}$.

\footnotetext{
33 İlkay Erken, "İskodra Vilayetinde Nahiye İdaresinin Uygulanması (1868-1912)", Sosyal Beşeri ve İdari Bilimlerde Akademik Araşttrmalar I, Mehmet Yavuz Erler ve Abdullah Şevki Duymaz (ed.), Gece Kitaplığı, Ankara 2018, s. 185-200.

${ }^{34}$ Şemseddin Sami, Kamus 'ul A 'lâm, C. VI., Mihran Matbaas1, İstanbul 1898, s. 4013.

35 İdari birimlerin düzenlenmesinin yanında Loros kazasındaki idarecilerle ilgili işlemler sürer. İstifa eden Avlonya kaymakamlığına Loros kaymakamı Faik Bey tayin edilir. Loros'a ise Hilmi Efendi kaymakam olarak görevlendirilir. Bk. B. O. A., İ.DH. 1072-84120, 1 Recep 1305/14 Mart 1888.

${ }_{36}$ B. O. A., DH.MKT. 1461-21, 19 Safer 1305/6 Kasim 1887.

${ }^{37}$ B. O. A. , SD. 418-72, 12 Şevval 1322/20 Aralık 1904.

${ }^{38}$ B. O. A., HRT.h. 351, 1 Zilhicce 1314/3 Mayls 1897. ;B. O. A. , HRT.h. 229, 1 Zilhicce 1341/15 Temmuz 1923.

${ }^{39}$ Y. V. S. , H. 1306/M. 1888, s. 112.

${ }^{40}$ Kazadaki okullardan birisinin kasaba merkezindeki ibtidai olduğu anlaşılır. 38 erkek öğrencinin öğrenim gördüğü okula ilerleyen yıllarda kız çoçuklarına mahsus diğer bir ibtidai dahil edilir. Bk. Y. V. S. , R. 1308/M. 1892, s. 119.; Y. V. S. , H. 1319/M. 1901, s. 177.

${ }^{41}$ Y. V. S. , H. 1306/M. 1888, s. 112, 136. ;Y. V. S. , R. 1308/M. 1892, s. 220.
} 
Loros'un asıl teşkil gerekçesi olan Müslüman muhacirlerin iskânı meselesi Narda'nın terki ile hayata geçirilir. 93 Harbi ardından Berlin Muahedesi gereğince terk edilen Narda kasabası beraberinde Narda kazasından birçok köy ve çiftlik Yunanistan'a bırakılmıştı. Osmanlı Devleti ile Yunanistan sınırının yeniden düzenlendiği bu anlaşma gereğince Narda kasabasındaki 1086 hane ve 1975 nüfus ile ikisi manastır olmak üzere 55 köyde toplam 4177 hane ve 9293 kişi Osmanlı sınırı dışında kalır. Yunanistan'a terk edilen bu yerlerden Osmanlı Devleti'nin vazgeçtiği gelir miktarı ise 1.177.900 kuruş civarındadır ${ }^{42}$. Loros kasabasındaki hane sayısı ise 60 iken tamamı Müslüman 336 kişi bulunmaktaydı. Loros kazasında ise 77 köy ve çiftlik vardı. Bahsedilen 77 köy ve çiftlik dahilinde 2695 hanede 6450 Hristiyan ve 400 Müslüman ki toplam 6850 kişi kalmıştı. Loros kazasından elde edilen gelir miktarının toplamı ise 2.114.007 kuruştan ibaretti. İlgili sınır düzenlemesinde toplamda 110 köy Osmanlı tarafında kalır. Ancak Loros kazası dahilindeki köy ve çiftlik sayısı görüldüğü üzere 77 'dir. Buradan anlaşıldığı kadarıyla sınır düzenlemesi sonrasında Osmanlı tarafinda kalan 110 köyden 77'si Loros, diğerleri ise vilayet dahilindeki diğer idari birimlere taksim edilmiştir ${ }^{43}$. Ancak takip edilebildiği kadarıyla Loros kazası dahilindeki köy ve çiftlik taksimatı ilerleyen yıllarda değişikliğe uğrar. 1888 yılında 81 'e ${ }^{44}$ çıkan bu sayı 1894 yılında 68 'e düşer. 1894 y1lında kaza dahilindeki köy ve çiftlik isimlerinin verildiği kaynaktaki listede bu durum çiftlik ve köylerin isimleriyle birlikte açıkça görülür ${ }^{45}$. Kaza bünyesindeki köy ve çiftlik dağılımı 1898 itibariyle aynen korunur ${ }^{46}$.

Loros'un teşkili ardından sahip olduğu tamamı Müslüman 336 kişinin Narda muhacirleri olup olmadığı kaynaklarda açık değildir. Konuya temas edilen çalışmalarda Loros'un, Narda muhacirlerinin iskânına elverişli bir İslam Beldesi olması düşüncesi ile kurulmasına ve buraya iskân edilecek muhacirlere meccanen arazi verilmesi doğrultusundaki fermana rağmen 1884 yllına kadar bahsedilen muhacirlerin iskân edilmediği nakledilir ${ }^{47}$. Bununla ilgili bilgilerin yer aldığı evrakta ise Narda'nın Yunanistan'a terki sırasında Narda kasabasında 500 kadar Müslümanın bulunduğu gösterilir. 1881 yılı içinde bunlardan 130 kadarı Yanya ve Preveze gibi yerlere hicret ederler $^{48}$. Lakin bu muhacirlerin iskân edildikleri yerler belirtilmediği gibi bunlardan kaçının Loros'a yerleştiği de bilinmez.

Durumun daha anlaşılır olması açısından Narda'nın Yunanistan'a terki öncesindeki nüfus yapısına bakılabilir. Bu açıdan Yanya eyaleti sınırlarında bir kaza olan Narda'nın 1846 yılında 233 köy ve çiftlikten oluştuğu tespit edilebilir ${ }^{49}$. Bu tarihten sonra ve Yanya vilayetinin teşkili yani 1867 yılından öncesine ait bilgilerin yer aldığı kaynakta

\footnotetext{
${ }^{42}$ B. O. A. , ŞD. 2090-31, 9 Kanunusani 1298/21 Ocak 1883.

${ }^{43}$ B. O. A. , SD. 2090-31, 9 Kanunuevvel 1298/21 Aralık 1882.

${ }^{44}$ Y. V. S. , H. 1306/M. 1888, s. 137.

${ }^{45}$ Tabloda sıralanan 72 köy ve çiftlik içerisinde ayrıca bazı manastırlar da bulunur. Bunlar dikkate alındığında esas sayının 68 olduğu görülür. Bk. Y. V. S. , R. 1311/M. 1894, s. 285-289.

${ }^{46}$ Şemseddin Sami, Kamus'ul A'lâm, C. VI., s. 4013.

${ }^{47}$ İpek, Rumeli'den Anadolu'ya Türk Göçleri, s. 176.

${ }^{48}$ B. O. A. , I. DH. 830-66814, 7 Haziran 1297/2 Temmuz 1881.

${ }^{49}$ B. O. A. , NFS. d. 5222, s. 2, 3-188, 29 Zilhicce 1262/18 Mart 1846.
} 
ise Narda kazasında 261 Müslüman, 6173 Hristiyan olmak üzere 6434 hane mevcuttur ${ }^{50}$. Bu kaynağın yanında 1875 yılında Narda kasabasının da dahil edilip erkeklerin dikkate alınarak kaza nüfusunun verildiği kaynakta 7169 hanede 17.246 kişi vardır. Bunlardan 267'si Yahudi, 16541'i Hristiyan ve 438'i Müslümandır ${ }^{51}$. Kazanın Müslüman ve Hristiyan erkek nüfus dağılımının gösterildiği Tablo 2'de görüldüğü üzere Müslümanların büyük kısmı Narda kasabasındadır.

Tablo 2: 1876 Yllı Narda Kasaba ve Kaza Nüfusu ${ }^{52}$.

\begin{tabular}{|l|l|l|}
\hline Narda & Hane & Erkek Nüfus \\
\hline Kasabadaki Müslümanlar & 186 & 360 \\
\hline Kasabadaki Hristiyanlar & 812 & 1692 \\
\hline Kasabadaki Yahudiler & 88 & 367 \\
\hline Kasabanın Toplamı & 1086 & 2419 \\
\hline Kazadaki Müslümanlar & 39 & 78 \\
\hline Kazadaki Hristiyanlar & 5417 & 13630 \\
\hline Kaza ve Kasaba Toplamı & 6542 & 16.127 \\
\hline
\end{tabular}

Narda'nın Osmanlı sınırları dışında kalmasından önceki nüfus yapısını gösteren pusulada ise 1876-1880 yılları arasındaki durum mukayese edilir. Buna göre doğum ve ölüm oranlarının milliyete göre miktarının gösterildiği pusulada Müslüman nüfus sayısına doğum ile 60 kişi eklenirken 99 kişi vefat eder. Hristiyanlarda ise beş yıllık dönemde 1849 doğum yaşanırken 1601 ölüm ile toplamda 248 kişi artar. Kasabadaki Yahudilerde 46 doğum ve 74 ölüm neticesinde nüfus sayılarında 28 kişilik bir azalma yaşanır. Böylece 1876-1880 yılları arasında kaza nüfusundaki toplam artış 181 kişi ile sınırlı kalır. Bu dönemde Eylül 1880 itibariyle Narda kasabasında 1060, kasaba dışındaki birimlerde 166 Müslüman vardır. Aynı tarihte kasabada 1813 Hristiyan, 340 Yahudi mevcut iken kasaba dışındaki Hristiyanların toplamı 15282'dir. Bu şekilde kazada 17095 Hristiyan, $1266{ }^{53}$ Müslüman ve 340 Yahudi ikamet etmekteyken kaza nüfusu 18701 'ir $^{54}$. 1876-1880 yılları arasındaki nüfus değişimi 1875 yılı bilgileri ile mukayese edildiğinde bazı uyuşmazlıklar görülmektedir. Bu durumu kaza dahilindeki bulaşıcı hastalıklardan ${ }^{55}$ kaynaklı ölümlerle açıklamak mümkündür ${ }^{56}$.

Bu bilgilerden hareketle Narda'nın Yunanistan'a terki öncesinde kasabada bini aşkın Müslümanın ikamet ettiği söylenebilir. Narda'nın Yunanistan'a terki sırasında hala 500 kadar Müslümanın kasabada bulunduğu verisi ise muhtemelen sadece erkeklerin

\footnotetext{
${ }^{50}$ Belgenin tarihlendirmesi sorunludur. Yanya vilayeti ifadesinin varlığı ve Narda'nın Osmanlı sınırlarında yer alması nedeniyle 1867 öncesine tarihlendirilebilir. Bk. B. O. A., Y.EE. 34-82, 6 Rabiulevvel 1327/28 Mart 1909.

${ }^{51}$ Y. V.S. , H. 1292/M. 1875, s. 106.

52 B. O. A. , Y.EE. 34-75, 13 Şubat 1291/25 Şubat 1876.

${ }^{53}$ Haziran ayına ait kaynakta bu sayı 1226, Hristiyanlar için ise 15560 olarak verilir. Bunun istatistiklerin oluşturulması sırasındaki hatalardan kaynaklanması muhtemeldir. Bk. B. O. A. , Y.MTV. 4-23, 19 Haziran 1296/1 Temmuz 1880.

${ }_{54}^{54}$ B. O. A. , Y.PRK.UM. 3-24, 22 Ağustos 1296/3 Eylül 1880.

${ }^{55}$ Tifo, sıtma ve kolera gibi hastalıkların Arnavutluk genelinde yaygın olduğuna da işaret edilir. Bk. Mary Edith Durham, The Burden Of The Balkans, Thomas Nelson and Sons, London 1905, p. 318.

${ }^{56}$ B. O. A. ,Y.PRK.UM. 3-47, 25 Eylül 1296/7 Ekim 1880.
} 
dikkate alınmasından kaynaklanmaktadır. Öğleki 1875 yılına ait kaynakta sadece erkek nüfus dikkate alınmıştır. 1880 yılı verilerinde ise Müslümanlar için erkek ve kadın sayısının birlikte verildiği anlaşılmaktadır. Bununla ilgili olarak 1883 yılına ait nüfus defterinde Loros kazası geneli için nüfus verileri gösterilebilir. Burada kazada 46 Yahudi, 1.168 Müslüman ve 15041 Hristiyan olmak üzere 16255 kişinin bulunduğu naklediliir ${ }^{57}$. $\mathrm{Bu}$ dönemde vilayet içerisindeki nüfusta toplu yer değişiklikleri olmadığ dikkate alındığında Loros kazasına Yunanistan'a terk edilen Narda'dan gelen muhacirlerin iskânlarının gerçekleştiği ileri sürülebilir. Ancak bir İslam Beldesi olması düşünülerek inşa edilen Loros'a 1888 yılı itibariyle Hristiyanların da yerleştiği bilinmektedir. Bu yıl kasabada 282 kadın 308 erkek toplam 590 Hristiyan bulunmaktadır. Müslümanlar için ise bu sayısı 311 kadın 461 erkek olmak üzere 772'dir. Böylece 1888 yılında Loros kasabasında 593 kadın 769 erkek ki toplam 1362 kişi yaşamaktadır ${ }^{58}$. 1882 ve 1883 yılı verilerinde bahsedildiği üzere Loros'un ilk teşkili esnasında kasabada sadece Müslüman 60 hanede 336 kişi mevcuttu. Bu sayı geçen süre zarfinda sadece Müslümanlar için dahi 336'dan 772'ye çıkmıştır. Bu ise Narda'da artık Müslüman nüfusun kalmadığını söylemek imkânını verir nitelikte bir bilgi olmaktadır. Nitekim kasaba dışındaki Müslüman nüfusun da dikkate alınmasıyla birlikte Loros kazası dahilindeki Müslümanların sayısı Yunanistan'a terk edilen Narda kazasındaki sayıyla neredeyse aynıdır.

Loros'a Narda'dan gelen muhacirlerin iskânlarının mevcut çiftliklerin tarımsal faaliyetlere imkân vermesinden ve Narda'ya yakınlığından sebeple hızlı bir şekilde yapıldığı ve bunun hazineye fazlaca yük getirmediği varsayılabilir. Loros'un teşkil gerekçesine uygun bir şekilde muhacirlerin yakın mesafedeki bir kasabaya yerleşmeleri düşüncesi ile kurulması ardından köy ve çiftliklerindeki nüfus dağılımı da 1894 tarihli istatistikte gösterilmektedir.

Tablo 3: Loros Kazası Dahilindeki Ciftlikler (1894) ${ }^{59}$.

\begin{tabular}{|l|l|l|l|}
\hline Ad1 & Hane & Kadın & Erkek \\
\hline 1-Aya yorği çiftliği & 29 & 56 & 73 \\
\hline 2-Aya Praşkoy Çiftliği & 40 & 108 & 121 \\
\hline 3-Istaroke Çiftliği & 52 & 45 & 47 \\
\hline 4-Astrovine Çiftliği & 37 & 114 & 133 \\
\hline 5-Astronekli Çiftliği & 14 & 25 & 27 \\
\hline 6-Asfelenko Çiftliği & 19 & 26 & 32 \\
\hline 7-Askoya Çiftliği & 65 & 142 & 133 \\
\hline 8-İmam Çavuş Çiftliği & 40 & 86 & 97 \\
\hline 9-Anze Çiftliği & 26 & 86 & 66 \\
\hline 10-Brenbeste Çiftliği & 63 & 103 & 97 \\
\hline 11-Bestina Çiftliği & 38 & 68 & 38 \\
\hline 12-Bulmet Çiftliği & 34 & 79 & 94 \\
\hline 13-Balişka Çiftliği & 22 & 51 & 52 \\
\hline 14-Balişoş Çiftliği & 6 & 18 & 21 \\
\hline
\end{tabular}

\footnotetext{
${ }^{57}$ B. O. A., NFS. d. 7450, s. 114-115, 29 Zilhicce 1300/31 Ekim 1883.

${ }^{58}$ Y. V. S. , H. 1306/M. 1888, s. 135.

${ }^{59}$ Y. V. S. , R. 1311/M. 1894, s. 285-289.
} 


\begin{tabular}{|c|c|c|c|}
\hline 15-Bikalmo Çiftliği & 30 & 148 & 165 \\
\hline 16-Papazates Çiftliği & 102 & 302 & 232 \\
\hline 17-Padole Çiffliği & 8 & 25 & 12 \\
\hline 18-Pandansa Çiftliği & 29 & 96 & 105 \\
\hline 19-Petra Çiftliği & 26 & 68 & 68 \\
\hline 20-Penaya Çiftliği & 18 & 50 & 66 \\
\hline 21-Podgore ${ }^{60}$ Çiftliği & 95 & 335 & 343 \\
\hline 22-Çabrazli Çiftliği & 51 & 160 & 179 \\
\hline 23-Çankaroplu Çiffliği & 23 & 55 & 66 \\
\hline 24-Çekripçi Çiftliği & 2 & - & - \\
\hline 25-Çoliste Çiftliği & 37 & 64 & 75 \\
\hline 26-Halkazis Bey Çiftliği & 8 & 15 & 13 \\
\hline 27-Halkazis Gino Çiftliği & 23 & 65 & 79 \\
\hline 28-Dara Çiftliği & 14 & 27 & 27 \\
\hline 29-Rapsiste Çiftliği & 114 & 210 & 340 \\
\hline 30-Rahi Çiftliği & 41 & 91 & 115 \\
\hline 31-Ropa Çiftliği & 6 & 21 & 23 \\
\hline 32-Zavaka Çiftliği & 12 & 19 & 22 \\
\hline 33-Osmaniye Çiftliği & 1 & - & - \\
\hline 34-Ali Bey Çiftliği & 23 & 60 & 63 \\
\hline 35-Umarto Çiftliği & 15 & 43 & 42 \\
\hline 36-Germeniçe Çiftliği & 51 & 111 & 111 \\
\hline 37-Geribove Çiftliği & 11 & 46 & 39 \\
\hline 38-Guripa Çiftliği & 14 & 49 & 33 \\
\hline 39-Guladis Çiftliği & 27 & 56 & 64 \\
\hline 40-Filapyada Çiftliği & 50 & 149 & 170 \\
\hline 41-Kaluberko Çiftliği & 26 & 45 & 48 \\
\hline 42-Kanca Çiftliği & 61 & 154 & 143 \\
\hline 43-Kanşos Çiftliği & 43 & 81 & 107 \\
\hline 44-Kraka Çiftliği & 77 & 186 & 291 \\
\hline 45-Klisore Çiftliği & 66 & 110 & 150 \\
\hline 46-Kostakos Çiftliği & 56 & 140 & 143 \\
\hline 47-Komcadis Çiftliği & 101 & 206 & 214 \\
\hline 48-Kolomeziya Çiftliği & 14 & 38 & 41 \\
\hline 49-Krasove Çiftliği & 9 & 32 & 40 \\
\hline 50-Kramanes Çiftliği & 7 & 26 & 25 \\
\hline 51-Kerkezates Çiftliği & 23 & 75 & 69 \\
\hline 52-Krenikolo Çiftliği & 17 & 52 & 52 \\
\hline 53-Leftrohor Çiftliği & 49 & 135 & 141 \\
\hline 54-Lelova Çiftliği & 155 & 399 & 475 \\
\hline 55-Mulana Çiftliği & 62 & 147 & 198 \\
\hline 56-Mitka Çiftliği & 18 & 49 & 49 \\
\hline 57-Milana Çiftliği & 19 & 44 & 59 \\
\hline 58-Naşari Çiftliği & 29 & 96 & 101 \\
\hline 59-Nanoy Çiftliği & 46 & 168 & 135 \\
\hline
\end{tabular}

${ }^{60}$ Podgora imlası ile bk. Osmanlı Bankası Arşivi, Hrt. 108118, Halil İbrahim Efendi, Yunanistan Haritası, H. 1314. 


\begin{tabular}{|l|l|l|l|}
\hline 60-Nesiste Çiftliği & 100 & 57 & 159 \\
\hline 61-Nihor Çiftliği & 130 & 397 & 415 \\
\hline 62-Nikoliç Çiftliği & 58 & 173 & 210 \\
\hline 63-Vorzu Çiftliği & 30 & 54 & 61 \\
\hline 64-Volana Çiftliği & 5 & 16 & 8 \\
\hline 65-Volisne Çiftliği ${ }^{61}$ & 19 & 52 & 58 \\
\hline 66-Viğala Çiftliği & 11 & 29 & 22 \\
\hline 67-Yorğotos Çiftliği & 31 & 66 & 67 \\
\hline 68-Yekbicar Çiftliği & 32 & 105 & 95 \\
\hline 69-Ayla Manastırı & 14 & 33 & 32 \\
\hline 70-Vlahorina Manastırı & 30 & 40 & 34 \\
\hline 71-Proğon Mezrası & 5 & 4 & 4 \\
\hline 72-Topaltı Mevki' & 9 & 11 & 9 \\
\hline $\begin{array}{l}\text { Loros Kazası Toplamı (Kasaba } \\
\text { Hariç) }\end{array}$ & 2870 & 6507 & 7137 \\
\hline Toplam & 13.644 Kişi & \\
\hline
\end{tabular}

Tabloda görüldüğü gibi Loros kasabası dışındaki kaza nüfusu 13644'tür. İslam Beldesi inşası çabalarına rağmen Loros kasabası dışında bunun tam olarak gerçekleştirildiği söylenemez. Nitekim Hristiyan nüfusun fazla olduğu Loros kazasına bu nedenle bir kaymakam yardımcısının ataması dahi gerekmiştir ${ }^{62}$. Loros kazasında 1899 yılında kurulması düşünülen nahiyelerin nüfusları kazanın demografik dağılımını sergiler niteliktedir. Tablo 4'te gösterilen nahiye nüfuslarına bakıldığında 11572 kişinin buralarda yaşadığı anlaşılır. Ancak kaza genelinde $20000^{63}$ kadar kişinin mevcudiyeti bununla birlikte değerlendirildiğinde kaza merkezine bağl1 köyler ile kasaba nüfusunun dikkate alınması gerekmektedir. Öğleki Tablo 1'de buradaki nahiyelere bağlanması düşünülen köy sayısı toplamda 40’tır. Geri kalan 28 köyün merkez kazaya dahil edilmesiyle durum netleşmektedir. Böylece Narda'dan gelen muhacirlerin iskân edildiği Loros kasabası aynı isimdeki kazanın merkezi olarak kazanın mülki sınırları dahilindeki köylerin büyük bölümünün doğrudan idari merkezidir. Bu köylerdeki ahalinin büyük kısmının Hristiyan olduğu görüldüğünde nüfus dağılımındaki çoğunluğa rağmen muhacirlerin iskânı ve güvenlik temelinde oluşturulan Müslümanların çoğunlukta olduğu kasaba idari merkez yapılmıştır.

Tablo 4: 1899 Yılında Teşkili Düşünülen Nahiyeler ve Nüfuslart ${ }^{64}$.

\begin{tabular}{|l|l|l|}
\hline Ad1 & Hane & Nüfus \\
\hline Lelove & 1074 & 5109 \\
\hline Kervansaray & 440 & 1793 \\
\hline Selhore & 282 & 1498 \\
\hline Köprübaş1 & 622 & 3172 \\
\hline Toplam & 2418 & 11572 \\
\hline
\end{tabular}

\footnotetext{
${ }^{61}$ Voliste imlası ile bk. Osmanlı Bankası Arşivi, Hrt. 108118, Halil İbrahim Efendi, Yunanistan Haritası, H. 1314.

${ }_{62}^{62}$ B. O. A., DH. TMIK.S. 3-103, 21 Teşrinisani 1312/3 Aralık 1896.

${ }^{63}$ Şemseddin Sami, Kamus'ul A'lâm, C. VI., s. 4013.

${ }^{64}$ B. O. A. , DH. TMIK.S. 28-85, 11 Teşrinisani 1315/23 Kasım 1899.
} 


\section{Sonuç}

Osmanlı Devleti'nin yaşadığı toprak kayıpları nedeniyle karşılaştığı meselelerin başında bu topraklardaki ahalinin göçü olmuştur. Kaybedilen topraklardan Osmanlı ülkesine göç etmek durumunda kalan muhacirlerin yeniden yaşamlarını idame ettirir düzeye gelmeleri yetkililerin önceliklerinden olmuştur. Muhacirlerin terk etmek zorunda kaldıkları topraklara benzer, içtimai bakımdan sorun yaşamayacakları yerlere iskânları bu açıdan önemliydi. Ayrıca muhacirlerin yerleştirilecekleri yerde hem kendi ihtiyaçlarını karşılamak hem de üretimi arttırarak ülke ekonomisine yapacakları katkı da önemsenmiştir. Bu açıdan muhacirlerin iaşe ve barınma meseleleri gibi maliyeye yük getiren durumların olabildiğinde hızlı bir şekilde ortadan kaldırılması önemsenmiştir. Yanya vilayetinin Yunanistan ile sınır bulunan Preveze sancağının Narda kazasının kaybı bu açıdan dikkat çeker. Yunanistan'a terk edilen Narda dahilindeki Müslümanların Osmanlı topraklarına yapacakları göç nedeniyle buna mahsus bir kasaba teşkili fikri bu açıdan önemlidir. Osmanlı yetkilileri Narda'ya bulunduğu konum itibariyle yakında yeni bir kasaba kurmak fikrine buraya yerleşecek Müslümanların daha az zahmet çekmeleri bakımından önem vermiştir. Siyasi ve askeri bakımdan ise Yunanistan'ın Narda ile yetinmeyerek kuzeye doğru genişlemek düşüncesi ile vilayetin asayişini etkileyecek hareketlerini engellemek düşüncesi de bunda etkiliydi. Muhacirlerin Narda'dan çok uzak olmayan bir yerde yerleşmelerinde bölgedeki ekilebilir arazilerin de mevcudiyeti dikkate alınmaktaydı. Böylelikle tarımsal üretime dair faaliyetler aksamayacak ve hatta üretim dolayısı ile Osmanlı Devleti'nin gelirleri artacaktı. Bu şekilde evraklarda da belirtildiği üzere Yunanistan'a terk edilen yerler sebebiyle vazgeçilen gelirlerin de ikamesi mümkün olabilecekti. Bu nedenlerle Osmanlı Devleti muhacirlerin iskânı içtimai, siyasi ve askeri gerekçelerle bir kasaba teşkil etmiştir. 
Kaynaklar

1.Arșiv Malzemesi

Başbakanlık Osmanlı Arşivi (B. O. A.)

Dahiliye Nezâreti Mektubî Kalemi (DH.MKT.)

Dahiliye Nezâreti Şifre Evrakı (DH.ŞFR.)

Dahiliye Nezâreti Tesrî-i Muamelât (DH.TMIK.S.)

İrâde Dahiliye (I.DH.)

İrâde Dahiliye (i.DH.)

İrâde Şûrâ-yı Devlet (I.ŞD.)

Nüfus Defterleri (NFS.d.)

Şûrâ-yı Devlet Evrakı (ŞD.)

Yıldız Esas Evrakı (Y.EE.)

Yıldız Mütenevvî Maruzât Evrakı (Y.MTV.)

Yıldız Parakende Evrakı Umumİ Vilayetler Tahrirâtı (Y.PRK.UM.)

Yıldız Sadâret Resmi Maruzât Evrakı (Y.A.RES.)

\subsection{Haritalar}

Başbakanlık Osmanlı Arşivi (B. O. A.), Haritalar (HRT.h. 351, 1 Zilhicce 1314/3 Mayıs 1897.

Başbakanlık Osmanlı Arşivi (B. O. A.), Haritalar (HRT.h.) 229, 1 Zilhicce 1341/15 Temmuz 1923.

Osmanlı Bankası Arşivi, Hrt. 108118, Halil İbrahim Efendi, Yunanistan Haritası, H. 1314.

\subsection{Salnameler}

Devlet Salnamesi (D. S.), H. 1298/M. 1881.

Devlet Salnamesi (D. S.), H. 1299/M. 1882.

Devlet Salnamesi (D. S.), H. 1300/M. 1883.

Devlet Salnamesi (D. S.), H. 1301/M. 1884.

Devlet Salnamesi (D. S.), H. 1302/M. 1885.

Yanya Vilayet Salnamesi (Y. V. S.), H. 1288/M. 1871.

Yanya Vilayet Salnamesi (Y. V. S.), R. 1308/M. 1892..

Yanya Vilayet Salnamesi (Y. V. S.), R. 1311/M. 1894.

Yanya Vilayet Salnamesi (Y. V. S.), H. 1292/M. 1875.

Yanya Vilayet Salnamesi (Y. V. S.), H. 1293/M. 1876.

Yanya Vilayet Salnamesi (Y. V. S.), H. 1306/M. 1888.

Yanya Vilayet Salnamesi (Y. V. S.), M. 1319/M. 1901.

\section{Kütüphane Malzemesi}

Ali Cevad, Memalik-i Osmaniyenin Coğrafyası, C.III., Kasbar Matbaası, İstanbul 1314.

Ali Tevfik, Mufassal Memalik-i Osmaniye Coğrafyası, Artin ve Asadoryan ve Mahdumları Matbaası, İstanbul 1329.

Baldacci, Antonio; Itinerari Albanesi (1892-1902), Presso La Reale Societa Geografica Italiana, Roma 1917. 
Berber, Ferhat; “19. Yüzyılda Kafkasya'dan Anadolu'ya Yapılan Göçler”, Karadeniz Araştırmalarl, S. 21, Güz 2011, ss. 17-49.

Bostan, İdris; "Narda", DİA. , C. 32, Türkiye Diyanet Vakfi Yayınları, İstanbul 2006, sS. 385-387.

Çelik, Züriye; “ Osmanlının Zor Yıllarında Rumeli Göçmenlerinin Türk Basınındaki Sesi: Muhacir Gazetesi (1909-1910)", Selçuk Üniversitesi Türkiyat Araştırmaları Dergisi, S. 28, 2010, ss. 403-413.

Destani, Beytullah (ed.); Albania and Kosovo; Political and Ethnic Boundaries 18671946, Archive Editions, Hobbs The Printers Of Southampton, Bristol 1999.

Durham, Mary Edith; The Burden Of The Balkans, Thomas Nelson and Sons, London 1905.

Erken, İlkay; “İşkodra Vilayetinde Nahiye İdaresinin Uygulanması (1868-1912)”, Sosyal Beşeri ve İdari Bilimlerde Akademik Araştırmalar I, Mehmet Yavuz Erler ve Abdullah Şevki Duymaz (ed.), Gece Kitaplığı, Ankara 2018, s. 185-200.

İpek, Nedim; Rumeli'den Anadolu'ya Türk Göçleri, Türk Tarih Kurumu Basımevi, Ankara 1999.

İpek, Nedim; Selanik'ten Samsun'a Mübadiller, Cevdet Yılmaz (haz.), Samsun Büyükşehir Belediyesi Yayınları, Samsun 2010.

Paşaoğlu, Derin Derya; “Muhacir Komisyonu Maruzatı'na Göre (1877-78) 93 Harbi Sonrası Muhacir İskânı”, History Studies, Vol. 5, Issue 2, March 2013, pp. 347386.

Pul, Ayşe; "1877-78 Osmanlı-Rus Savaşı Sonrası Beykoz'da Muhacirler İçin İskân Yeri Çalışmaları”, Tarih Okulu Dergisi, S. XV, Eylül 2013, ss. 159-182.

Qasımova, Sevinç; "XIX Yüzyılda Kuzey Kafkasya'dan Anadolu'ya Göçler: Tarihçilik Açısından Göçün Nedenleri, Sorunları ve Sonuçları", Akademik Tarih ve Düşünce Dergisi, C. IV. S. XIII, Aralık 2017, ss. 589-624.

Şahin, Naci; "XIX. Yüzyıl Sonrasında Anadoluya Yapılan Göç Hareketleri Ve Anadolu Coğrafyasındaki Sosyo-Kültürel Etkileri”, Sosyal Bilimler Dergisi, ss. 63-82.

Şemseddin Sami, Kamus'ul A’lâm, C. VI. Mihran Matbaası, İstanbul 1898. 
